\title{
Rancang Bangun Aplikasi Telemedika untuk Pasien Diabetes Berbasis Platform iOS
}

\author{
Septian Rheno Widianto \\ Prodi Teknik Media Digital, Jurusan Teknik Informatika dan Komputer \\ Politeknik Negeri Jakarta \\ Jl. Prof. G.A. Siwabessy, Kampus UI, Depok \\ septian.rheno@yahoo.de
}

Diterima: 10 Maret 2017. Disetujui: 12 April 2017. Dipublikasikan: Mei 2017

\begin{abstract}
Abstrak - Telemedika adalah praktik kesehatan dengan memakai komunikasi audio visual dan data, termasuk perawatan, diagnosis, konsultasi dan pengobatan serta pertukaran data medis dan diskusi ilmiah jarak jauh. Diabetes Mellitus (DM) merupakan salah satu penyakit degeneratif, terjadi gangguan metabolisme karbohidrat, lemak dan protein serta ditandai dengan tingginya kadar gula dalam darah (hiperglikemia) dan dalam urin (glukosuria). Berdasarkan hasil evaluasi analisis, dan perancangan, maka disimpulkan bahwa dengan pengembangan aplikasi GLUTApp dapat memfasilitasi penginputan, penyimpanan, dan pemantauan hasil pemeriksaan kadar gula darah. GLUTApp juga memudahkan pasien diabetes dalam menyimpan dan mengolah medical record dengan adanya media penyimpanan pada database yang dapat diakses oleh pengguna. Para pengguna dapat menerima notifikasi yang efektif terkait dengan medical record yang dinput. GLUTApp memberikan kemudahan bagi guardian dan dokter dalam memantau kesehatan pasien dan memungkinkan untuk memberikan rekomendasi resep obat, tindakan dan rumah sakit terdekat dengan menggunakan smartphone berbasis iOS.
\end{abstract}

Kata Kunci: telemedika; diabetes mellitus; GLUTApp; iOS.

\section{PENDAHULUAN}

Telemedika memiliki cakupan yang luas, meliputi penyediaan pelayanan kesehatan (termasuk klinis, pendidikan dan pelayanan administrasi) jarak jauh, melalui transfer informasi (audio, video, grafik), dengan menggunakan perangkat-perangkat telekomunikasi (audio-video interaktif dua arah, komputer, dan telemetri) dengan melibatkan dokter, pasien dan pihak- pihak lain [1]. Data para pasien atau penderita sakit disimpan secara electronically serta referensi informasi buku-buku kesehatan. Revolusi di bidang kesehatan telah memberikan keuntungan. Tahap selanjutnya informasi-informasi akan disimpan melalui smartphones yang merupakan alat instrumen di dalam evolusi ini. Teknologi yang sedang dikembangkan pada saat ini salah satunya pada bidang kesehatan. Kesehatan merupakan hal yang sangat berharga untuk itulah perlu dikembangkan suatu teknologi yang mampu menjembatani antara dokter dengan pasien tanpa harus bertemu secara langsung. Teknologi ini adalah Telemedika (telemedicine).

DM adalah suatu penyakit yang disebabkan oleh karena peningkatan kadar gula dalam darah (hiperglikemi) akibat kekurangan hormon insulin, absolut ataupun relatif. Absolut berarti tidak ada insulin sama sekali sedangkan relatif berarti jumlahnya cukup atau memang sedikit tinggi atau daya kerjanya kurang [2]. DM dibagi menjadi beberapa tipe. DM tipe I biasanya menimbulkan gejala sebelum usia pasien 30 tahun, walaupun gejala dapat muncul kapan saja. Pasien DM tipe I memerlukan insulin dari luar tubuhnya untuk kelangsungan hidupnya. DM tipe II biasanya dialami saat pasien berusia 30 tahun atau lebih, dan pasien tidak tergantung dengan insulin dari luar tubuh, kecuali pada keadaan-keadaan tertentu. Tipe DM lainnya adalah DM gestasional, yakni DM yang terjadi pada ibu hamil, yang disebabkan oleh gangguan toleransi glukosa pada pasien tersebut [3]

Secara epidemiology, diperkirakan bahwa pada tahun 2030 prevalensi Diabetes Melitus (DM) di Indonesia mencapai 21,3 juta orang (Diabetes Care, 2004). Berdasarkan hasil riset di perkirakan jumlah penderita Diabetes di dunia akan mencapai 300 juta orang [4]. Penyakit diabetes tidak datang secara tiba- 
tiba, namun dalam keadaan darurat Penanganan cepat sangat dibutuhkan. Penanganan tersebut bisa berupa cek gula darah atau pun meminum minuman yang mengandung gula, yang bertujuan untuk menambahkan jumlah kalori dalam tubuh penderita. Gejala-gejala diabetes antara lain:

1. Dehidra

2. Rasa haus terus-menerus

3. Peningkatan frekuensi

4. Kelelahan

5. Penurunan berat badan

6. Gangguan penglihatan

7. Penyembuhan luka yang lama

Dari gejala-gejala diatas penderita diabetes harus dapat mengukur berat badan, mengatur pola makan, dan berolahraga serta mengkonsumsi obat secara rutin dan tepat waktu. Tidak semua kegiatan tersebut haruslah dilakukan dengan pergi ke dokter secara rutin, melainkan dapat dilakukan secara mandiri dirumah. Inilah peran telemedika dalam menyelesaikan permasalahan ini [5]. Dari latar belakang yang telah disampaikan, bisa ditarik kesimpulan bahwa kebutuhan akan adanya aplikasi telemedika di Indonesia khususnya penyakit diabetes relatif tinggi. Keterlambatan komunikasi dapat memberikan resiko yang cukup tinggi terutama bila penderita sudah menderita penyakit kronis. Untuk itulah diperlukan sebuah aplikasi telemedika, sebagai media komunikasi jarak jauh antar pasien dan dokter.

\section{DASAR TEORI}

\section{A. Mobile Phone}

Mobile phone (cell phone) adalah perangkat elektronik portabel yang berfungsi sebagaimana pesawat telepon normal, yang dapat bergerak pada suatu area yang luas (bandingkan dengan cordless phone). Mobile phone saat ini menggunakan kombinasi transmisi radio dan telephone circuit switching (PSTN) konvensional, walaupun packet switching sudah digunakan untuk beberapa bagian jaringan mobile phone, khususnya untuk layanan akses Internet dan WAP.

Mobile phone atau lebih sering disebut dengan Telepon genggam adalah perangkat telekomunikasi elektronik yang mempunyai kemampuan dasar yang sama dengan telepon konvensional saluran tetap, namun dapat dibawa ke mana-mana (portable, mobile) dan tidak perlu disambungkan dengan jaringan telepon menggunakan kabel (nirkabel; wireless).

\section{B. Telemedicine}

Telemedicine adalah aplikasi dari pengobatan klinis yang pengembangannya memanfaatkan telepon, internet, dan jaringan komunikasi lain untuk mentransfer informasi medis. Istilah telemedicine sering disalahartikan dengan istilah e-health ataupun telehealth. Telemedicine hanya merujuk pada layanan klinis, sedangkan telehealth mencakup baik layanan klinis maupun layanan nonklinis seperti pendidikan, administrasi, dan penelitian bidang medis. Sedangkan e-health digunakan pada istilah yang mencakup telehealth, rekam medis elektronik, dan komponenkomponen lain dalam kesehatan TI (teknologi informasi).

Dalam praktek pelaksanaannya, telemedicine diterapkan dalam dua konsep yaitu:

- Real time (synchronous)

Telemedicine secara real time (synchronous telemedicine) dapat berbentuk sederhana seperti penggunaan telepon, atau yang kompleks seperti penggunaan robot bedah. Synchronous telemedicine memerlukan kehadiran dua pihak di waktu yang sama. Media penghubung diperlukan yang dapat menawarkan interaksi secara real time sehingga salah satu pihak dapat melakukan penanganan kesehatan. Contohnya penggunaan teknologi teleotoscope yang memberikan fasilitas untuk sorang dokter yang melihat ke dalam pendengaran pasien dari jarak jauh. Contoh lainnya yaitu tele-stethoskop yang membuat seorang dokter mendengarkan detak jantung pasien dari jarak jauh.

- $\quad$ Store and forward (asynchronous)

Telemedicine dalam store-and-forward (asynchronous telemedicine) mencakup pengumpulan data medis dan pengiriman data ini ke seorang dokter pada waktu yang tepat untuk evaluasi offline. Jenis ini tidak memerlukan kehadiran kedua belah pihak dalam waktu yang sama. Dermatologi, radiologi, dan patologi adalah spesialis yang biasanya menggunakan teknologi ini. Rekam medis dalam struktur yang tepat dalah komponen utama dalam transfer ini.

Telemedicine paling bermanfaat untuk masyarakat yang tinggal di daerah terpencil ataupun daerak yang jauh. Saat ini telemedicine diterapkan secara virtual untuk semua bidang medis. Spesialis yang menggunakan telemedicine sering menggunakan prefix tele. Contohnya telemedicine yang diterapkan oleh radiologist disebut teleradiology, telemedicine yang diterapkan oleh cardiologist disebut telecardiology. Telemedicine sangat bermanfaat sebagai alat komunikasi antara praktisi umum dan spesialis yang berada di lokasi yang jauh. Pemantauan pasien di rumah, dengan menggunakan 
perangkat-perangkat yang dikenal umum seperti tekanan darah dan mengirimkan informasi tersebut ke caregiver (orang yang bertanggung jawab atas kesehatan pasien, yaitu keluarga pasien) di tempat yang jauh. Solusi pemantauan jarak jauh difokuskan pada penyakit kronis dengan morbiditas tinggi.

\section{Teknologi Telemedicine}

Teknologi telemedicine terdiri dari teknologi perangkat keras dan perangkat lunak. Teknologi perangkat keras telemedicine:

- Jaringan komputer / internet

Teknologi ini dapat menghubungkan antar hingga dapat saling komunikasi dan bertukar data. Jaringan komputer dapat menghubungkan komputer di gedung yang berbeda, kota yang berbeda bahkan seluruh dunia. Teknologi lebih dikenal dengan internet. Jaringan komputer ini tidak hanya dengan kabel tetapi juga nirkabel. Jaringan komputer termasuk internet mampu menciptakan synchronous maupun asynchronous telemedecine.

\section{- Satelit}

Satelit dapat mengatasi tempat-tempat yang tidak terjangkau. Satelit saat ini dipakai untuk dijadikan infrastruktur komunikasi seperti telepon. Satelit memperluas jangkauan telemedicine ke darah-daerah terpencil atau lokasi yang sulit dibangun infrastruktur jaringan kabel.

\section{- Handphone}

Fungsi utama handphone adalah untuk komunikasi suara dan teks (SMS), namun fiturfitur tambahan ditambahkan seperti: $M M S$, fasilitas ini dapat mengirim suara, gambar, maupun video, GPRS atau $3 \mathrm{G}$, fasilitas ini menambah kecepatan pengiriman data ke handphone sehingga dapat dikirim secara realtime sehingga dapat dilakukan video conference, juga dapat dilakukan chatting atau browsing internet, Software, yaitu misalnya dengan teknologi Java dengan java ME (mobile edition) dapat ditambahkan dalam HP.

\section{- Plug-play device}

Teknologi yang memungkinkan penambahan piranti baru dalam komputer. Setiap computer akan dilengkapi dengan berbagai port. Melalui port-port tersebut piranti baru dapat ditambahkan dalan komputer. Ada beberapa port yang ada saat ini diantara port serial, port pararel, dan USB. Port tersebut peralatan multimedia dapat dihubungkan ke komputer, sehingga audio conference maupun video conference dapat dilakukan. Piranti kesehatan juga dapat dihubungkan dengan komputer lewat port ini, contohnya stetoskop, thermometer, USG, laboratorium.

- Teknologi multimedia

Multimedia disini adalah yang berkaitan dengan media suara, gambar, dan video. Semuanya dapat bersifat digital dan dapat dikirim secara digital juga.

Teknologi perangkat lunak yang mendukung telemedicine:

- Teknologi chatting dan conference

Chatting biasanya dilakukan antara 2 orang berbeda di komputer yang berbeda. Sedangkan conference dapat dilakukan lebih dari dua orang yang berbeda tetapi dalam satu forum. Salah satu software ini misalnya yahoo messenger, google talk, dan software chatting yang lain.

- Pengolahan citra

Pengolahan citra adalah salah satu bidang kajian di dunia perangkat lunak komputer. Bidang ini mengkaji teknik-teknik mengolah citra (gambar, foto). Pengolahan citra menawarkan teknik-teknik untuk mengolah citra termasuk memperbaiki citra sebelum dikirm ke tempat lain.

- Teknologi pemampatan (kompresi) data

Teknik ini mengubah data berukuran besar menjadi data berukuran kecil. Pengubahan tidak akan menghilangkan informasi di dalamnya. Karena data hasil kompresi berbeda dengan data sebelumnya, maka diperlukan proses dekompresi.

\section{Diabetes}

Diabetes merupakan penyakit kronik yang melemahkan kandungan karbohidrat, protein, dan lemak yang dihasilkan oleh insulin. Tiap sel dalam tubuh membutuhkan energi untuk bekerja dan sumber utama energi tersebut adalah glukosa. Segala makanan yang mengandung karbohidrat menghasilkan glukosa yang berjalan dalam darah sebagai sumber energi sel [6].

Insulin merupakan hormon yang dihasilkan oleh pankreas, yang bekerja sebagai mediator sehingga glukosa dapat masuk ke dalam darah. Ketika insulin yang dihasilkan relatif sedikit, maka glukosa akan diam dalam darah dan tidak masuk ke sel. Menyebabkan kondisi yang disebut hyperglycemia. Tubuh akan berusaha untuk membuang glukosa yang berlebih dalam darah, namun sel tidak dapat mengambil glukosa karena kekurangan hormon insulin. 


\section{E. Xcode}

Xcode adalah suatu alat pemrograman besutan Apple untuk membuat aplikasi yang dijalankan dalam lingkungan Apple (iOS dan MacOS). Alat pemrograman seperti Xcode ini biasa disebut juga dengan Integrated Development Environment (IDE), seperti Visual Studio dan Eclipse. Xcode mendukung beberapa bahasa pemrograman seperti $\mathrm{C}, \mathrm{C}++$, Objective $\mathrm{C}$ dan yang terakhir mendukung bahasa Swift yang tersedia pada Xcode 6 .

Xcode menyediakan semua kebutuhan pemrograman seperti editor, compiler, debugger dan run-time simulator. Selain itu Xcode juga dilengkapi dengan fasilitas management pengembangan aplikasi seperti repository dan version control. Xcode terintegrasi dengan aplikasi git dan memudahkan untuk melakukan kegiatan software configuration management untuk kerja tim.

\section{F. $\quad$ Sistem Operasi iOS}

Sistem operasi perangkat bergerak yang dikembangkan dan didistribusikan oleh Apple Inc. Sistem operasi ini pertama diluncurkan tahun 2007 untuk iPhone dan iPod Touch, dan telah dikembangkan untuk mendukung perangkat Apple lainnya seperti iPad dan Apple TV. Tidak seperti Windows Phone (Windows CE) Microsoft dan Android Google, Apple tidak melisensikan iOS untuk diinstal di perangkat keras non-Apple.

Pada 12 September 2012, App StoreApple berisi lebih dari 700.000 aplikasi iOS, yang secara kolektif telah diunduh lebih dari 30 miliar kali. SO ini memiliki pangsa pasar $14,9 \%$ untuk unit sistem operasi perangkat bergerak telepon cerdas yang dijual pada kuartal ketiga 2012, terbanyak setelah Android Google. Pada bulan Juni 2012, iOS mencakup 65\% konsumsi data web perangkat bergerak (termasuk di iPod Touch dan iPad). Pada pertengahan 2012, terdapat 410 juta perangkat bergerak yang diaktifkan. Menurut Apple pada tanggal 12 September 2012, 400 juta perangkat bergerak iOS telah dijual sepanjang bulan Juni 2012.

Antarmuka pengguna iOS didasarkan pada konsep manipulasi langsung menggunakan gerakan multisentuh. Elemen kontrol antarmukanya meliputi slider, switch, dan tombol. Interaksi dengan SO ini mencakup gerakan seperti geser, sentuh, jepit, dan jepit buka, masing-masing memiliki arti tersendiri dalam konteks sistem operasi iOS dan antarmuka multisentuhnya. Akselerometer internalnya dipakai oleh sejumlah aplikasi agar bisa merespon terhadap pengguncangan alat (misalnya membatalkan tindakan) atau memutarnya dalam tiga dimensi (misalnya beralih dari mode potret ke lanskap).

iOS diturunkan dari OS $\mathrm{X}$, yang memiliki fondasi Darwin dan karena itu iOS merupakan sistem operasi Unix. iOS adalah versi bergerak dari sistem operasi OS $\mathrm{X}$ yang dipakai dikomputer-komputer Apple. Lapisan abstraksi yang terdapat pada iOS, yaitu Core OS, Core Services, Media, dan Cocoa Touch. Versi terbaru sistem operasi ini (iOS 6.0) menyisihkan 1-1,5 GB memori perangkat bergerak untuk partisi sistem dengan memakai $800 \mathrm{MB}$ partisi (tergantung model) untuk iOS-nya saja.

\section{METODOLOGI PENELITIAN}

Penelitian ini menggunakan peralatan komputer, perangkat lunak xcode dan platform iOS. Langkahlangkah penelitiannya adalah sebagai berikut:

1) Studi Literatur: Metode analisis dengan mempelajari sumber-sumber yang berasal dari buku, artikel, dan untuk mendapatkan landasan dasar penulisan paper.

2) Observasi: Melakukan pengamatan dan mempelajari aplikasi yang sejenis dengan aplikasi yang akan dikembangkan untuk mendapatkan data dan informasi yang berguna untuk pengembangan aplikasi dan penulisan paper.

3) Kuesioner: Metode pengumpulan masukan dan evaluasi dari responden yang sesuai yaitu pasien diabetes mengenai aplikasi yang akan dikembangkan.

4) Planning: Pada tahap ini dilakukan kegiatan penyusunan-penyusunan fitur yang dibutuhkan, dan fitur-fitur baru yang perlu dikembangkan serta estimasi dan penjadwalan waktu untuk membangun dan merancang aplikasi yang akan dibuat.

5) Modelling: Pada tahap perancangan ini dilakukan desain analisis berdasarkan hasil pada tahap sebelumnya seperti UML (unified modeling language) yang akan dibuat untuk pengembangan aplikasi ini antara lain adalah: Use-Case Diagram, Activity Diagram, Sequence Diagram, Class Diagram.

6) Construction: Pada tahap ini dilakukan coding aplikasi berdasarkan planning dan modeling yang menghasilkan rancangan fiturfitur yang akan dimiliki aplikasi. Prinsip coding sederhana dan tidak berlebihan untuk menghindari kompleksitas pada aplikasi yang sedang dibangun.

7) Testing: Pada tahap ini dilakukan pengujian aplikasi yang telah berhasil dibangun pada 
tahap sebelumnya. Tujuannya adalah untuk menguji dan memastikan kembali bahwa fitur yang telah dirancang dapat berjalan sesuai dengan yang diharapkan. Proses pengujian dilanjutkan dengan melakukan acceptance tests, aplikasi akan di review oleh pasien diabetes sebagai sasaran user untuk memastikan bahwa aplikasi telah memenuhi dan sesuai dengan kebutuhan user.

\section{PEMBAHASAN}

Desain user interface sesuai dengan pengguna yaitu para penderita diabetes, sehingga user pengguna aplikasi akan menerima notifikasi yang efektif terkait dengan medical record yang di input. Memberikan kemudahan kepada guardian dan dokter dalam memantau kesehatan pasien dan memungkinkan untuk memberikan rekomendasi resep obat, tindakan dan rumah sakit terdekat dengan menggunakan smartphone.

A. Perbandingan Terhadap Fungsi dan Menu Aplikasi

1) Berusaha Untuk Konsisten. Aplikasi yang dikembangkan menggunakan jenis dan warna tulisan, serta warna latar belakang yang seragam untuk semua tampilan.

2) Memberikan kemudahan bagi user Aplikasi GLUTApp membantu user dengan memberikan kesan pada masing-masing fitur aplikasi sehingga dapat mudah untuk dipahami.

3) Memberikan feedback yang optimal. Aplikasi GLUTApp mampu memberikan umpan balik atas kegiatan yang telah dilakukan user misalnya dengan pewarna pada record tertentu dan memberikan pilihan.

4) Merancang dialog untuk menghasilkan penutup

Aplikasi GLUTApp memberikan tanggapan berupa pesan dialog kepada user untuk user atas perubahan yang telah dilakukan, misalnya perubahan biodata, penghapusan record, serta dialog emergency.

5) Memberikan penanganan masalah sederhana. Aplikasi GLUTApp juga memiliki penanganan kesalahan sederhana seperti ketika user lupa mengaktifkan GPS pada saat ingin menggunakan layanan emergency berbasis lokasi.
6) Mendukung pengendali internal Aplikasi GLUTApp memberikan kendali bagi user untuk melakukan penyesuaian settings, misalnya pengaturan batas atas dan batas bawah kadar gula darah.

7) Memberikan reminder. Aplikasi GLUTApp juga memiliki fasilitas reminder yang diperuntukan bagi pengguna yang merupakan penderita diabetes mengenai medical record, pola makan teratur harian, diet bagi penderita diabetes.

8) Mengurangi beban ingatan jangka pendek. Aplikasi GLUTApp membantu user dengan mengurangi ingatan jangka pendek, seperti informasi pada bagian atas untuk menunjukan posisi user pada saat itu serta penggunaan gambar sebagai icon utama.

9) Memberikan Statistik. Aplikasi GLUTApp menampilkan statistic dan progress harian bagi penderita diabetes, statistik tersebut digunakan untuk melihat perkembangan kesehatan penderita diabetes.

10) Terkoneksi Social Media. Aplikasi GLUTApp dapat terkoneksi ke media sosial pengguna aplikasi yang merupakan penderita diabetes, pengguna dapat membagikan tips, cerita dan motivasi kepada teman-teman pengguna Aplikasi GLUTApp melalui media sosial.

\section{B. Perbandingan Aplikasi Sejenis}

1. OnTrack : Data Record, Statistic, Reminder, Notes, Chats/Graphs, Report/Export, Social Media, Link/Informations, Monitoring, AutoNotifications, Emergency Support.

2. DiabetesPlus : Data Record, Statistic, Notes, Chats/Graphs, Report/Export, Social Media, Link/Informations, AutoNotifications, Emergency Support.

3. Glucose Buddy : Data Record, Reminder, Notes, Chats/Graphs, Report/Export, Social Media, Link/Informations, Monitoring, AutoNotifications, Emergency Support.

4. Curo Diabetes : Data Record, Notes, Chats/Graphs, Report/Export, Social Media, Link/Informations, Monitoring, AutoNotifications, Emergency Support, Monitoring, AutoNotifications, Emergency Support, Monitoring, AutoNotifications, Emergency Support

5. GLUTApp : Data Record, Statistic, Reminder, Notes, Chats/Graphs, Report/Export, Social Media, Link/Informations, Monitoring, 
AutoNotifications, Emergency Support, Monitoring, AutoNotifications, Emergency Support.

Aplikasi GLUTApp memiliki fitur berupa AutoNotification sehingga pengguna akan mendapatkan notifikasi terkait dengan data yang telah disimpan oleh pengguna, Emergency push call yang dapat melakukan panggilan terhadap dokter yang telah terhubung, dan Emergency support based on location. Fitur Emergency support based on location memberikan bantuan dengan melakukan pencarian terhadap rumah sakit terdekat dari lokasi pengguna. GLUTApp juga didukung dengan fitur Statistic, Reminder, dan Social Media yang bertujuan sebagai penunjang fitur yang ada pada aplikasi GLUTApp.

\section{KESIMPULAN}

Berdasarkan hasil evaluasi analisis, dan perancangan, maka hal-hal yang dapat disimpulkan dari pengembangan GLUTApp adalah:

1) Aplikasi GLUTApp memfasilitasi penginputan, penyimpanan, dan pemantauan hasil pemeriksaan kadar gula darah.
2) Memudahkan pasien diabetes dalam menyimpan dan mengolah medical record dengan adanya media penyimpanan pada database yang dapat diakses oleh pengguna.

3) Para pengguna dapat menerima notifikasi yang efektif terkait dengan medical record yang di input.

4) Memberikan kemudahan kepada guardian dan dokter dalam memantau kesehatan pasien dan memungkinkan untuk memberikan rekomendasi resep obat, tindakan dan rumah sakit terdekat dengan menggunakan smartphone berbasis iOS.

\section{REFERENSI}

[1] Idris, S.1992. Pengantar Teknologi Pengolahan Susu, Animal Husbandry Project, Universitas Brawijaya, Malang.

[2] Medicastore. (2009). Diabetes Mellitus, 1.0. [Accesed 20 Maret 2017]., from medicastore.com/index.php? $\bmod =$ penyakit\&id $=135$

[3] Regina 2012. Komplikasi Diabetes Melitus. Diabetes Melitus.org Pusat Informasi Penyakit DM. Available from: http:// diabetesmelitus. org/ komplikasi- diabetes- melitus/ [Accessed 20 Maret 2017].

[4] Chaudhary, F. D., Chaudhary, S. D., Masood, K., \& Qadri, S. K. (2010). Evaluation of Lifestyle Modification in Diabetes Patients. Nishtar Medical Journal, 2.

[5] Nur. (2007). 7 Gejala Diabetes yang Wajib Anda Tahu.

[6] Taylor, S. E. (2006). Health Psychology. (6th. Ed), Singapore: Mc. Graw Hill Book Company. 